\section{Przestrzenie Zagłady w perspektywie ekologiczno-nekrologicznej ${ }^{1}$}

\section{Ewa Domańska}

TEKSTY DRUGIE 2017, NR 2, S. 34-60

DOI: $10.18318 /$ td.2017.2.3
Artykułzostał przygotowany w ramach grantu Narodowego Centrum Nauki przyznanych na podstawie decyzji DEC-2013/IIIB/HS3/02075. Stanowi on wersję jednego z rozdziałów książki: Nekros. Wprowadzenie do ontologii martwego ciała (Warszawa: PWN, w druku).
Węgiel jest kluczowym pierwiastkiem materii żywej. [...] [B]łyskawiczna praca trójki: dwutlenku węgla, światła i zieleni roślin, dotychczas nie została dostatecznie opisana. [...] A przecież ową lekką i zwinną chemię "wynalazły" dwa czy trzy miliardy lat temu nasze ciche siostry - rośliny [...]. Takie jest życie, chociaż rzadko tak się je opisuje: polega na przyłączaniu się, dryfowaniu dla własnej korzyści, pasożytowaniu na wędrówce energii w dół, od jej postaci słonecznej do zdegenerowanej formy ciepła o niskiej temperaturze. To na tej wędrówce, która prowadzi do równowagi, a zatem do śmierci, życie kreśli swoje meandry i na niej się zasadza. Znowu jesteśmy dwutlenkiem węgla [.t.1.://rcin. org . pl

Primo Levi Wegiel ${ }^{2}$

1 Tekst zawiera fragmenty artykułu: E. Domańska Dehumanisation Through Decomposition and the Force of Law, trans. by P. Vickers, w: Mapping the 'Forensic Turn:' The Engagements with Materialities of Mass Death in Holocaust Studies and Beyond, ed. by Z. Dziuban, New Academic Press, Vienna 2017, s. 83-98.

2 P. Levi Węgiel, w: tegoż Układ okresowy, przeł. Z. Koprowska, Wydawnictwo Literackie, Kraków 2011, s. 327-328 i 331-332.

\section{Ewa Domańska}

- profesor nauk humanistycznych w Instytucie Historii Uniwersytetu im. Adama Mickiewicza w Poznaniu oraz od 2002 visiting associate professor w Department of Anthropology, Stanford University. Zajmuje się współczesną teorią i historią historiografii oraz porównawczą teorią nauk humanistycznych. Autorka i redaktorka m.in. książek: Historia egzystencjalna (2012); Historia - dziś (red. z R. Stobieckim iT. Wiśliczem, 2014). Kontakt: ewa.domanska@amu.edu.pl 
Systemy glebowe postępują z martwymi ciałami, dokładnie tak, jak z każdą inną formą substancji organicznej; to ludzka perspektywa czyni z nich szczególnie wyjątkową postać tej materii.

David Barclay, Lorna A. Dawson et al. Soils in Forensic Science ${ }^{3}$

W Nauce Nowej (1744) Giambattista Vico wskazał na trzy podstawowe zwyczaje, na których opiera się ludzka cywilizacja. Są nimi: religia, małżeństwo i grzebanie zmarłych. Ich przestrzeganie, jego zdaniem, chroni ludzkość przed popadnięciem w stan barbarzyństwa ${ }^{4}$. Idąc tropem włoskiego myśliciela, znany afroamerykański filozof, pisarz i aktywista Cornel West, rozważając rolę humanistów w świecie, napisał:

Biorę całkowicie na poważnie ustęp dwunasty z Nauki Nowej Vico, w którym mówi on o humanistyce jako derywacie słowa humanitas, pochodzącym z kolei od łacińskiego humando, co znaczy „grzebanie”. Pracować w humanistyce to zaczynać od masowości pogrzebanych ciał, z którymi musimy się zmierzyć. ${ }^{5}$

Wypowiedź Westa rozumiem dosłownie, a prowadzone w ramach humanistyki badania traktuję jako mierzenie się z masowością otaczających nas szczątków ${ }^{6}$. Wobec m.in. coraz bardziej zaawansowanych technologii umożliwiających podtrzymywanie życia, wyrafinowanych sposobów rozkładu zwłok oraz przetwarzania i wykorzystywania ludzkiej materii organicznej, a także

3 A.D. Barclay, L.A. Dawson et al. Soils in Forensic Science: Underground Meets Underworld, w: Criminal and Environmental Soil Forensics, ed. by K. Ritz, L. Dawson, D. Miller, Springer, Dordrech 2009, S. 507 [501-513].

4 G. Vico Nauka Nowa, przeł. J. Jakubowicz, PWN, Warszawa 1966, s. 138-139 (\&333).

5 C. West, Chekhov, Coltrane and Democracy, w: The Cornel West Reader, Basic Books, New York 1999 , s. 551.

6 Według danych całkowita liczba ludzi urodzonych od początku istnienia ludzkości przekracza 107 miliardów, z czego żyje 7 miliardów ludzi, a pozostałe sto miliardów stanowią zmarli. Liczby te uświadamiają, że ziemia na której żyjemy, ma humiczne (od humus) podstawy. Zob.: C. Haub How Many People Have Ever Lived on Earth?, "Population Today" November/December 2002 Vol. 30, No. 8 (uaktualnione dane są dostępne w Internecie: C. Haub How Many People Have Ever Lived on Earth?, http://www.prb.org/Publications/Articles/2002/HowManyPeopleHaveEverLivedonEarth.aspx (7.12.2015). Problem ten podejmuje również: Antoon de Baets A Declaration of the Responsibilities of Present Generations Toward Past Generations, "History and Theory" 2004 Vol. 43, No. 4, s. 131 [130-164]. 
kurczącego się miejsca na cmentarzach (i pod zakładanie nowych nekropolii) status martwego ciała i szczątków zmienia się zasadniczo. Postawę proponowaną przez Westa uważam za ważną także w kontekście szerszego problemu: żyjemy bowiem w świecie, w którym zarówno śmierć, jak i martwe ciało są dyskryminowane. Przez dyskryminację rozumiem szczególny przywilej nadawany żywym bytom, a marginalizowanie i wykluczenie tych, które uważamy za nie-żywe lub martwe. Celem prowadzanych przez mnie w ramach dead body studies badań jest zatem próba problematyzacji binarnego rozumienia pojęć: żywe/martwe, a co się z tym wiąże, martwego ciała i różnych form tego, co po nim pozostaje.

W kontekście powyższych refleksji w artykule tym proponuję ekologiczno-nekrologiczne podejście do rozważań na temat specyficznych przestrzeni poobozowych, a także innych miejsc występowania grobów masowych. Interesują mnie przy tym inspiracje oferowane przez tafonomię (naukę badającą pośmiertny los szczątków organicznych) oraz ekologię dekompozycji, które pozwalają na odmienne od humanistycznego podejście do ontologicznego statusu martwego ciała i szczątków ludzkich. Zamiast traktowania ich w kategoriach tabuizowanego i budzącego wstręt transi lub estetyzujących rytów pogrzebowych czy/i wzniosłości żałoby oferują one humanistom ujęcie szczątków jako organiczny habitat i wielogatunkową formę życia. By wykazać przydatność takiego podejścia, w tekście tym podejmę problem dehumanizacji i postaram się wskazać, jak może zmienić się rozumienie szczątków, kiedy rozważania na temat zostaną przeniesione ze sfery kultury do biologicznie postrzeganych procesów rozkładu zachodzących w przestrzeniach grzebalnych. Odwołam się także do książki Caroline Sturdy Colls Holocaust Archaeologies (2015), by wykazać zasadność uzupełnienia i włączenia do rozważań na temat Holokaustu rzadko obecnych w humanistyce badań prowadzonych przez archeologię sądową (i ogólnie forensykę) ${ }^{7}$.

7 Terminy forensic i forensic sciençe/s nie maj)ą,(1aki|twierdzą specjaliści, w języku polskim właściwych odpowiedników. Zazwyczaj są one tłumaczone jako medycyna sądowa i nauki sądowe czy sądownicze, co nie oddaje jednak ich złożoności. Łacińska etymologia wskazuje bowiem na forum i forēnsis, co zwraca uwagę zarówno na sąd, jak i przestrzeń debaty publicznej (przedstawianie sprawy na forum publicznym). Leszek Kordylewski (State Crime Laboratory w Chicago; członek American Academy of Forensic Scientists) zaproponował zatem, by do współczesnego języka polskiego wprowadzić określenia forensyka i forensyczny, http://kordynet.com/ forensics.html (1.06.2016). W polskich publikacjach zastosowanie tego pomysłu znajdujemy W artykule Ewy Kulińskiej, Zastosowanie logistyki w forensyce, "Logistyka" 2015 nr 3, s.21-23. Sceptyczni są natomiast autorzy tomu Archeologia sądowa w teorii i praktyce, którzy obstają przy tłumaczeniu forensic archaeology jako archeologii sądowej, uznając, że termin archeologia 
Specyficzny naukowy słownik zarówno ekologii, jak i kryminalistyki może, jak sądzę, wzbogacić ramę teoretyczną i język prowadzonych przez humanistów rozważań na temat ludobójstwa, a tym samym sproblematyzować istniejące interpretacje i otworzyć możliwości nowych opcji badawczych. Należy jednak wziąć pod uwagę, że słownik ów nie oferuje neutralnych pojęć opisowych, lecz preskryptywne. Tym samym buduje specyficzną wizję rzeczywistości (zarówno przeszłej, jak i przyszłej). W przypadku ekologii jest to utopijna wielogatunkowa ekumena, w której wszystko łączy się ze wszystkim na zasadach współzależności różnych form życia (convivality, entanglements), a kryminalistyki - dystopia wszechobecnej kontroli i (prze)-mocy prawa rządzona mitem obiektywnej nauki, mistyką DNA, wyobrażeniem otaczającej rzeczywistości jako potencjalnej sceny zbrodni i obywatela jako możliwego przestępcy.

Potraktuję ekologię i kryminalistykę jako dyskursywne laboratorium, w którym dzięki refleksji dotyczącej ontologii martwego ciała mogę spekulować na temat „nadchodzącej przyszłości”, rozważając zagadnienia wielogatunkowych kolektywów, relacji między ludzkimi i nie-ludzkimi formami życia, możliwości myślenia o przyszłości w kategoriach symbiotycznych związków i nekrosymbiozy, jako specyficznym ich typie ${ }^{8}$. Zmieniając ramę dociekań na temat przestrzeni poobozowych z zainteresowanej przede wszystkim problemami pamięci i reprezentacji przeszłości perspektywy kulturowo-społeczno-politycznej na przyszłościową - ekologiczno-nekrologiczną (przy czym, rzecz jasna, nie twierdzę, że owe opcje się wykluczają), uzyskamy inne sugestie co do możliwości rozumienia tych miejsc szczególnego nagromadzenia szczątków oraz postępowania z nimi. Perspektywa eko-nekro ${ }^{9}$ zachęca do rozpatrzenia ich tożsamości w kategoriach morfologii postHolokaustowych przestrzeni, ich przekształceń, badania struktur wielowarstwowej rzeźby

forensyczna jest sztuczny, zaś pomysł Kordylewskiego spolszczenia angielskich słów nie jest

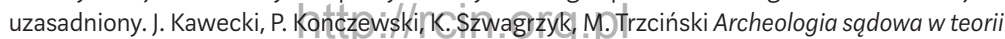
i praktyce, red. M. Trzciński, LEX, Warszawa 2013, s. 17.

8 Odmiennie jednak od Christophera W. Smithmyera, który pisze o nekrosymbiozie, rozważając konflikty polityczne, nie chodzi mi o rozpad relacji symbiotycznych, ale o to, że z punktu widzenia życia organicznego szczątki są elementem łączącym, mieszającym gatunki i wspomagają wystąpienie relacji symbiotycznych między organizmami. Ch.W. Smithmyer Necrosymbiosis, "Journal of Alternative Perspectives in the Social Sciences" 2009 Vol. 1, No. 3, s. 527-543. Death in Jim Crace's Being Dead. Mosaic, "A Journal for the Interdisciplinary Study of Literature" September 2015 Vol. 48, No. 3, s. 191-207. 
terenu, procesów zachodzących na powierzchni ziemi, nad nią i pod nią ${ }^{10}$. Perspektywa ta pozwala także badać sprawcze siły przyrody, które często ujawniają bezsilność działań człowieka (ludzką sprawczość), kwestionując przyznawaną sobie centralną pozycję w świecie.

Inspirujący kontekst perspektywy ekologicznej zachęca, by na specyficzne zjawisko, jakim są przestrzenie poobozowe, spojrzeć nie tyle czy nie tylko jako na element krajobrazu kulturowego, lecz ekologicznego"11 (często określanego także krajobrazem śmierci - deathscape ${ }^{12}$ ), lecz także jako na swoisty ekosystem (czy raczej zbiór różnorodnych ekosystemów), który stanowi ważne repozytorium biologicznej różnorodności ${ }^{13}$. Dokonujące się tam zmiany pozwala zaś widzieć nie tylko w kategoriach mierzalnego zegarem codzienności czasu chronologicznego, lecz także czasem cyklicznym wyznaczanym przez procesy wzrostu, rozkwitu, ginięcia i rozkładu. Zachęca też do ich umiejscowienia w ramach długiego trwania (nawet czasu geologicznego), co - jak sądzę - jest potrzebne, by zbalansować (w proponowanym tu ujęciu)

10 Na temat przestrzennej morfologii w interesujący sposób pisze Sophia Psarra, Spatial Morphology, Urban History and Design in Julienne Hanson's 'Urban Transformations: A History of Design Ideas', "The Journal of Space Syntax" 2012 Vol. 3, No. 1, s.7-19.

11 S. Whatmore, S. Hinchliffe Ecological Landscapes, w: The Oxford Handbook of Material Culture Studies, ed. by M.C. Beaudry, D. Hicks, Oxford University Press, Oxford 2010, s. 439-454. Pierwszym znanym mi artykułem, który proponował rozważanie przestrzeni poobozowych w kategoriach krajobrazu ekologicznego, był tekst: A. Charlesworth, M. Addis, Memorialization and the Ecological Landscapes of Holocaust Sites: The cases of Plaszow and Auschwitz-Birkenau, "Landscape Research" 2002 Vol. 27, No. 3, S. 229-251. Autorzy interesowali się przede wszystkim sposobami zarządzania tymi terenami, które - jak twierdzili, nie biorą pod uwagę kwestii ekologicznych.

Deathscapes: Spaces for Death, Dying, Mourning and Remembrance, ed. by A. Maddrell. J.D. Sidaway, Ashgate, Surrey 2010. Martin Pollock pisze o "skażonych krajobrazach", określając tak zawierające szczątki anonimowych ofiar miejsca mordów, które usiłowano zamaskować, m.in. sadząc drzewa. M. Pollock Skażone krajobrazy, przeł. K. Niedenthal, Czarne, Wołowiec 2014. Zob. także: T. Cole Holocaust Landscapes, Bloomsbury, London-New York 2016. Określenia "przestrzenie Holokaustu” używa, ale W innym niż proponowane tutaj rozumieniu, D. Stone Holocaust Spaces, w: Hitler's Geographies, ed. by P. Giaccaria, C. Minca, University of Chicago Press, Chicago-London 2016, s. 45-66.

Ujęcie takie proponują badacze zajmujący się bioróżnorodnością cmentarzy. G.W. Barrett, T.L. Barrett Cemeteries as Repositories of Natural and Cultural Diversity , "Conservation Biology" December 2001 Vol. 15, No. 6, , s. 1820 [1820-1824]; A. Uslu, E. Bariş, E. Erdoğan Ecological Concerns over Cemeteries, "African Journal of Agricultural Research" December 2009 vol. 4 (13), s. 1505-1511; I. Kowarika, S. Buchholz, M. von der Lippea, B. Seitz Biodiversity Functions of Urban Cemeteries: Evidence from one of the Largest Jewish Cemeteries in Europe , Urban Forestry \& Urban Greening" 2016 Vol. 19, s. 68-78. 
myślenie w kategoriach doraźnych interesów (krótkie trwanie) i uchwycić zarówno pożytki, jak i potencjalną niewspółmierność wobec możliwych zagrożeń w przyszłości zazwyczaj krótkotrwałych i związanych z cyklami politycznymi/wyborczymi (3-5-letnich) planów zarządzania terenami byłych obozów Zagłady.

Należy jednak podkreślić, że oferowane tutaj podejście nie proponuje ekocentrycznego czy scjentystycznego podejścia do badań przestrzeni Zagłady, które miałoby je zastąpić czy zdominować. Stanowi jedynie propozycję rozszerzenia i uzupetnienia badań Holokaustu prowadzonych w ramach humanistyki o aspekt ekologiczny ${ }^{14}$ iforensyczny, co miałoby doprowadzić do połączenia perspektyw oferowanych przez humanistykę i nauki społeczne z jednej strony oraz nauki o Ziemi i nauki o życiu z drugiej w celu zbudowania modelu komplementarnych badań zarówno tego, co działo się z terenami, na których istniały obozy zagłady i koncentracyjne, w przeszłości, jak i ich obecnego stanu oraz planowania ich losów w przyszłości. W proponowanym tutaj ujęciu perspektywa ta w żadnym razie nie podważa myślenia o człowieku jako ofierze ludobójstwa, nie neutralizuje wyrządzonego przez Holokaust cierpienia i krzywd ani nie ignoruje rozważań na temat traumy, pamięci i sprawiedliwości. Nie estetyzuje także przyrody, która zalecza skażoną przestrzeń, odczyniając tym samym zło, które tam się dokonało ${ }^{15}$. Chodzi natomiast o wskazanie często

O wykorzystaniu ekokrytyki do badań Holokaustu prowadzonych w ramach literaturoznawstwa pisze Aleksandra Ubertowska "Kamienie niepokojq̨ się i stajq się agresywne”. Holokaust w świetle ekokrytyki, „Poznańskie Studia Polonistyczne, Seria Literacka” 2015 nr 25 (45), s. 93-111.

Odwiedzając obozy Zagłady, Eric Katz zwrócił uwagę na roślinność, która - jak pisze, przeszkadzała mu kontemplować zło, które się tam wydarzyło. Dostrzega analogię między ludobójstwem i ekobójstwem (s. 315). Zarówno relacjami międzyludzkimi, jak i stosunkiem człowieka do przyrody rządzi jego zdaniem relacja dominacji, zawłaszczania, narzucania. Neutralizacja antropocentrycznego popędu do panowania nad naturą spowoduje, jak twierdzi, także zmianę postępowania ludzi wobec siebie. Katz pisze tak: „Podobnie jak odtworzony [restored] przez człowieka krajobraz ma inną hisstorię/przyczyn [jego powstania] niż autentyczny system naturalny, tak też odrodzenie Natury w miejscu ludobójstwa i destrukcji opiera się na serii ludzkich zdarzeń, które nie mogą zostać wymazane. Naturalna roślinność, która pokrywa masowy grób na warszawskim cmentarzu, nie jest tą samą roślinnością, która by tam rosła, gdyby ten grób nie został tam nigdy wykopany. Trawa i drzewa na tym cmentarzu mają inną przyczynę, inną historię, która jest nierozerwalnie związana z historią Holokaustu. Łąka na miejscu pola zbiórek w Majdanku nie przykrywa i nie koi błota i ruin obozu śmierci - wyrasta raczej z pyłu i prochów ofiar, które tam zginęły. Dla każdego, kto rozumie Holokaust [...], bogactwo Natury nie może ani zatrzeć, ani uleczyć horroru. Kiedy spoglądamy na procesy powodowane działalnością Przyrody w miejscach, gdzie dokonywał się Holokaust, widzimy kolejne przykłady jej panowania nad ludzkością [Nature's imperialism over humanity] - zwierciadlane odbicie 
totalnego (eko-genocydalnego) wymiaru destrukcji; o pokazanie, że eksterminacja nie dotyczyła tylko człowieka (i kultury, i jej dóbr), lecz w sposób zasadniczy wpłynęła także na przekształcenia krajobrazu, często niszcząc także zasoby natury ${ }^{16}$.

Prowadzone tutaj rozważania przenika etyczna troska o poszanowanie miejsc przechowujących ludzkie szczątki i o zachowanie ich godności. Kieruje nią respekt wobec zasad traktowania martwego ciała i szczątków oraz sposobów i miejsc pochówku w tradycji żydowskiej (a także w dużej mierze chrześcijańskiej), która nie dopuszcza rozkopywania cmentarza, jego likwidacji czy powtórnego wykorzystania. Zgodnie z jej zasadami „ciało powinno być pochowane w taki sposób, by nie utrudniać pełnego zespolenia z ziemią", a ekshumacje możliwe są tylko w „ściśle określonych przypadkach"17. Doron Kornbluth, który wyjaśnia podejście do zgodnej z wielowiekową tradycją inhumacji, wobec coraz bardziej popularnej kremacji, zwraca uwagę, że w Talmudzie można znaleźć przyrównanie grzebania do sadzenia (Sanhedryn 9ob, Ketubot 111b). Pochówek konwencjonalny symbolizuje włączenie ciała w cykl natury, natomiast kremacja - jego zdaniem, manifestuje zwycięstwo technologii i podbój natury ${ }^{\mathbf{1 8}}$. Można zatem założyć, że rozważania na temat dekompozycji ciała, które obracając się w proch (humus) i ulegając mineralizacji,

ludzkiej destrukcji środowiska przyrodniczego. Przyroda działa tutaj - bez intencji i planu, by zatrzeć pozostałości ludzkiego zła. [...] Odrodzenie Natury w miejscach Holokaustu jest formą panowania: zdominowania znaczenia. Przyroda powoli rozciąga swoją władzę nad rozwojem ludzkich idei, ludzką historią i pamięcią. W takim kontekście, myślenie o leczącej mocy Natury - leczącej mocy czegokolwiek - może wydawać się formą zawłaszczania". E. Katz Nature's Healing Power, the Holocaust, and the Environmental Crisis, w: Judaism and Environmental Ethics: A Reader, ed. by M.D. Yaffe, Lexington Books, Lanham 2001, s. 317 [308-320].

Często było też inaczej: zakładanie ogrodów i uprawę pól można bowiem traktować jako wzbogacenie ekosystemu i uatrakcyjnienie krajobrazu, co wiązało się z katorżniczą pracą więźniów. Zob.: J. Małczyński, KrajobrażyZZäłładaw perspekktywie posthumanistycznej, „Historyka” 2015 Vol. 45, s. 66 i n. [55-77]. Ideę „eksterminacji krajobrazu” znalazłam w artykule Mariusza Kistowskiego Eksterminacja krajobrazu Polski jako skutek wadliwej transformacji społeczno-gospodarczej państwa, w: Studia krajobrazowe a ginqce krajobrazy, red. D. Chylińska, J. Łach, Uniwersytet Wrocławski. Instytut Geografii i Rozwoju Regionalnego, Wrocław 2010.

Kilka słów o cmentarzach żydowskich i obyczajach zwiq̨zanych z pogrzebem, oprac. K. Bielawski, Serwis „KIRKUTY”, http://www.kirkuty.xip.pl/ciekawostkipelny.htm (12.08.2016). Por. także: S. Philip de Vries Obrzędy i symbole Żydów, przeł. A. Borowski, Wydawnictwo WAM, Kraków 2000. 
zmienia swoją formę, ale nie substancję, nie pozostają w sprzeczności z tradycją (ani też z ideą zmartwychwstania).

W tle tych przemyśleń znajduje się także problem nekrobójstwa, które rozumiem tutaj jako zabijanie tego, co już martwe, w sensie postępowania z martwym ciałem i szczątkami, pogwałcania prawa do godnego pochówku oraz nienaruszalności grobu. Postępowanie z ciałami zmarłych ofiar, m.in. palenie zwłok w obozowych krematoriach i dołach, stanowiło specyficzny rodzaj wielokrotnego nekrobójstwa, związanego z chęcią jak najszybszego i najbardziej efektywnego pozbycia się ciał oraz zamaskowania zbrodni. Mamy tu zatem do czynienia z nekrocydem zarówno w sensie pogwałcenia tradycji pochówku inhumacyjnego, jak i niegodnego sposobu spopielania oraz postępowania ze szczątkami mającego na celu ich nienaturalną dezintegrację (m.in. mielenie kości) czy utylizację (m.in. przerób szczątków lub wykorzystanie prochów jako nawóz), a także powtórnego otwierania grobów w celu spalenia ciał i zatarcia śladów mordu.

W kontekście zagrożeń związanych ze zwrotem forensycznym ${ }^{19}$ warto zwrócić uwagę, że prowadzone na coraz większą skalę ekshumacje ofiar ludobójstw i masowych mordów (proponowane także w przypadku Holokaustu) mogą stanowić strategię osiągania ostatecznej prawdy o zbrodniach (corpus delicti jako niepodważalny materiał dowodowy), domykania ich historii i wchodzenia w fazę zapominania ${ }^{20}$. Taka możliwość stoi w sprzeczności z przenikającą prowadzone tutaj rozważania ideą, że ludobójstwo rozumiane

19 W recenzji wydawniczej książki Human Remains and Identification czytamy: „Książka ta dowodzi, że pojawienie się nowych technologii ułatwiających identyfikację ludzkich zwłok zaowocowało pojawieniem się zwrotu forensycznego [forensic turn] normalizującego ekshumację jako metodę badania ludzkich szczątków na skalę masową". Human Remains and Identification: Mass Violence, Genocide and the 'Forensic Turn', ed. by A. Anstett, J.-M. Dreyfus, Manchester University Press, Manchester 2015, http://www.bookendsandbeginnings.com/ book/9780719097560 (14.5.2015). Lore Colaert, piszac o ekshumacjach ofiar hiszpańskiej wojny domowej, dostrzegając skalę zjawiska, używa terminu "ruch ekshumacyjny" (exhumation movement). L. Colaert Excavating a Hidden Past: The Forensic Turn in Spain's Collective Memory, w: Excavating Memory: Sites of Remembering and Forgetting, ed. by M.T. Starzmann, J. Roby, University Press of Florida, Gainesville 2016.

Takie właśnie przesłanki kierowały argumentami wielu matek ofiar „Brudnej Wojny” w Argentynie, które nie godziły się na ekshumację, twierdząc, że nie mają one nic wspólnego ze sprawiedliwością, a stanowią jedynie celową politykę państwa zmierzającą do zamknięcia sprawy desaparecidos. Piszę o tym w tekście: Archeologia martwego ciała. (Argentyńscy desaparecidos), w: E. Domańska Historie niekonwencjonalne. Refleksja o przeszłości w nowej humanistyce, Wydawnictwo Poznańskie, Poznań 2006, s. 181 i n. [161-194]. 
jako proces ${ }^{21}$, w taki czy inny sposób, nadal trwa, a jego ofiary żyją tak długo, jak istnieją po nich pozostałości (natura - pośmiertne trwanie materii organicznej w przekształconej formie) oraz jak często są wymieniane ich imiona (kultura - pamięć).

Dołączając się do deklarowanego m.in. przez Fredrica Jamesona odrodzenia myślenia skierowanego ku przyszłości (revival of futurity) i oferując w tym kontekście własną ideę nekrofuturyzmu, postawię taką tezę: w świetle nowych tendencji technologicznej utylizacji zwłok (m.in. hydroliza alkaliczna, wykorzystywanie prochów jako naturalny nawóz oraz tzw. recycling cmentarzy) losy zarówno zdeponowanych w ziemi szczątków, jak i samych miejsc grzebalnych w przyszłości budzą poważne obawy ${ }^{22}$. Trudno w tym miejscu nie wspomnieć Giorgio Agambena, który, pisząc o „poniżaniu śmierci” w Auschwitz, o „fabrykowaniu trupów” (samych w sobie już nie-ludzkich), wskazuje jedynie możliwą przyszłość. Jak twierdzi, obóz koncentracyjny to „nowy biopolityczny nomos planety"23. W świetle takich przewidywań umożliwienie

21 S.P. Rosenberg Genocide Is a Process, Not an Event, "Genocide Studies and Prevention”, Spring 2012 Vol. 7, No. 1, s. 26-23.

„Promessa Organic Burial” oferuje bezpieczną dla środowiska metodę liofilizacji ludzkich zwłok. Umożliwia ona skondensowanie zwłok dorosłego człowieka w 20-30 kilogramów organicznego proszku, który może posłużyć jako kompost. Jak sugeruje reklama: „Promessa wychodzi z założenia, że każdy rodzaj organicznej materii powinien podlegać recyklingowi”. Innym przykładem jest amerykański Urban Death Project, który według założeń twórców "jest nowym systemem wykorzystującym naturalny proces dekompozycji w celu bezpiecznego i łagodnego przekształcania naszych zmarłych w glebę", http://www.deathlab.org/research_disposition_promession.php (7.12.2015); https://www.kickstarter.com/projects/54646919o/the-urban-death-project-layingour-loved-ones-to-r/description (6.06.2014). Zob. także: C. Einhorn A Project to Turn Corpses Into Compost, , The New York Times" 13.04.2015, http://www.nytimes.com/2015/04/14/science/a-project-to-turn-corpses-into-compost.html?smid=tw-nytimes\&_r=4 (6.06.2016). W Norwegii aktualnie praktykuje się wstrzykiwanie do wnętrza grobów roztworu wapna w celu przyspieszenia dekompozycji. Proces ten określa się mianem „rehabilitacji cmentarzy”. E. Emmerentze Jervell Grave Problem: Nothing Is Rotting in the State of Norway ", The Wall Street Journal", 10.10.2013, http:// www.wsj.com/news/articles/SB10001424052702303342104579097100412815862 (19.03.2016). Warto także odnotować powstawanie nowego pola badawczego związanego z traktowaniem szczątków jako odpadów i ich wykorzystaniem. Parafrazując Zygmunta Baumana, można zatem mówić o "śmierci na przemiał” oraz o zwłokach jako ludzkich odpadach. Zob.: P.R. Olson, Knowing "Necro-Waste”. "Social Epistemology" 2016 Vol. 30, No. 3, s. 326-345, a także: Z. Bauman Życie na przemiał, przeł. T. Kunz, Wydawnictwo Literackie, Kraków 2005.

23 G. Agamben Co zostaje z Auschwitz. Archiwum i świadek, przeł. S. Królak, Sic!, Warszawa 2008, s. 70 i n., oraz tegoż Homo Sacer: Suwerenna władza i nagie życie, przeł. M. Salwa, Prószyński i S-ka, Warszawa 2008, s. 241 (część trzecia: Obóz jako biopolityczny paradygmat nowoczesności, rozdz. 7: Obóz jako nomos nowoczesności). 
i zabezpieczenie naturalnej mineralizacji szczątków, ich rozproszenie, zmieszanie i włączenie w naturalny, biologiczny cykl życia może je uchronić przed potencjalnym barbarzyństwem naukowym i technologicznym, np. przed ich przemysłową utylizacją (nawóz), wykorzystaniem w celach medialnych (nekroestetyka, pornografia szczątków) czy w doraźnych celach politycznych (ekshumacje jako sposób radzenia sobie z trudną przeszłościąa ${ }^{24}$ ).

\section{Archeologia sądowa w badaniach Holokaustu}

W swojej ważnej i potencjalnie przekształcającej prowadzone w ramach humanistyki badania nad Holokaustem, obszernej monografii - Holocaust Archaeologies. Approaches and Future Directions (2015), zajmująca się archeologią sądową badaczka - Caroline Sturdy Colls (Staffordshire University, Anglia) deklaruje, że „książka ta analizuje, jak nowe podejścia do badań kryminalistycznych i archeologicznych pomagają ujawnić dowody [zbrodni]"25. Dla Colls archeologia Holokaustu jest przede wszystkim dyscypliną śledczą, która wszystkie ślady przeszłości postrzega jako dowody zbrodni. Dzieje się tak zgodnie ze znaną zasadą sformułowaną w 1910 roku przez francuskiego klasyka badań kryminalistycznych - dra Edmonda Locarda (1877-1966), która stanowi, że „każdy kontakt pozostawia ślad” (every contact leaves a trace). Archeolog zaś owe ślady lokalizuje, pomaga identyfikować i interpretować. Takie podejście pozostaje w zgodzie z ogólnym założeniem wyjściowym autorki, dla której „Holokaust był i stale jest zarówno zbrodnią, jak i wydarzeniem historycznym" (s. 10, por. s. 149). W książce jak mantra potarza się sformułowanie, że „miejsca, w których dokonywał się Holokaust są także scenami zbrodni” (s. 199; s. 265 i 266). Dlatego też „odkopywanie grobów masowych nie tyle związane jest ze znajdywaniem ludzkich szczątków, ile $\mathrm{z}$ analizowaniem miejsca zbrodni" (s. 189, por. także: s. 228). W takim kontek-

hiem ekshumowani stanowią dla mnie specyficzny rodzaj martwego podmiotu (nekropersony). Jako historyk nie kwestionuję zasadności przeprowadzania ekshumacji w celu dochodzenia do prawdy o przeszłości, identyfikacji ofiar i oddania im sprawiedliwości. Wskazuje jednak, że z punktu widzenia etyki, a także religii (co pozostaje stałym tematem dyskusji m.in. archeologów) jest to problem, zwłaszcza jeżeli (jak było w przypadku ofiar zbrodni katyńskiej) ekshumacji dokonuje się wielokrotnie, a szczątki uprzedmiotawia, często rozprasza i traktuje jako materiał dowodowy w oderwaniu od kontekstu życia codziennego ofiar i ich rodzin. 
ście archeolog staje się według Colls nie tylko ekspertem w dziedzinie badań przedmiotów materialnych, lecz także krajobrazu i jego antropogenicznych przekształceń (s. 4 i 8). Krajobraz rozumiany jako miejsce i scena zbrodni staje się tutaj podstawową kategorią badawczą, a celem badań są zmiany, które w nim zaszły w wyniku zakładania obozów, a co się z tym wiąże, budowy dróg, wycinki lasów, zakładania cegielni, ogrodów itd. Ważne są także zmiany zachodzące w glebie i w roślinności związane z rozkładem znajdujących się tam szczątków ludzkich (groby masowe). Krajobraz jest zatem rozumiany jako asamblaż różnego rodzaju śladów materialnych (dowodów rzeczowych) ujawniających kompleksowość zbrodni, przygotowywań do niej, sposobów popełniania oraz zacierania i maskowania świadectw jej zaistnienia (s. 235).

Archeologia sądowa (posiłkująca się najnowszymi metodami badań kryminalistycznych) staje się w takim ujęciu zasadniczym (jeżeli nie podstawowym) sposobem badań Zagłady. Ponieważ jednak miejsca masowych mordów są zarówno scenami zbrodni, jak i miejscami świętymi (s. 65), szanując reguły religii, Colls promuje nieinwazyjne metody badań tych miejsc (s. 65 i n.) Poszanowanie wiary związane z postępowaniem z miejscami pochówku zgodnym z prawem halachicznym jest dla autorki imperatywem (s. 78). Mimo tych deklaracji, w książce czytamy jednak, że „jest nadzieja, że [w] przyszłości wraz z postępem technologii zostanie podjęty większy wysiłek w celu identyfikacji ofiar Holokaustu" (s. 193). Colls podkreśla także zasadność i wagę prowadzenia badań łączących humanistykę z naukami przyrodniczymi. Informacje uzyskane podczas prac archeologicznych na temat zmian zachodzących w krajobrazie ze względu na dokonane zbrodnie i ich efekty, pozostałości zabudowy obozów i grobów stanowią uzupełnienie, a jednocześnie wyzwanie dla narracji historycznych (por. s. 326) i relacji świadków (s. 343). Archeologia w ujęciu Colls ma zatem zarówno dopełniać, jak i uzupełniać (complement and suplement, s. 343) historię tego okresu.

Badaczka ma rację, pisząc, że wykorzystanie współczesnych metod badań archeologicznych pozwala spojrzeć|nałrajobrazy Zagłady w inny sposób. W ich świetle stają się one swoistymi archiwami procesów depozycyjnych i podepozycyjnych ${ }^{\mathbf{2 6}}$. Lotniczy skaning laserowy (LIDAR), prospekcja termiczna, badania geofizyczne (m.in. metody magnetyczne, badania

26 Podobnie dla historyków środowiska „każde miejsce jest archiwum, które zbiera materialne ślady swojej przeszłości, a continuum tego niepisanego archiwum umożliwia napisanie bardzo długiej historii każdego miejsca". W.J. Turkel Every Place is an Archive: Environmental History and the Interpretation of Physical Evidence, "Rethinking History” 2006 Vol. 10, No. 2, s. 268 [259-276]. 
elektrooporowe), różne metody badań powierzchniowych pozwalają dokonać analizy przestrzeni obozów i weryfikują narracje historyczne (i świadectwa), zgodnie z którymi po zbrodni nie zachowały się żadne ślady ${ }^{27}$. Kryminalistyka nie dopuszcza takiej możliwości, bowiem każda zbrodnia pozostawia ślad ${ }^{28}$. Badania archeologiczne podważają także przekonanie, że „szansę na przetrwanie mają tylko te ślady istnienia obozu, które pozostają widoczne i znajdują się na powierzchni ziemi"29. Przekonują, że jest wprost przeciwnie: największe szanse na zachowanie ma to, co właśnie nie jest widoczne i pozostaje zdeponowane w ziemi.

Potraktuję to krótkie streszczenie podejścia proponowanego przez Colls jako punkt wyjścia do dalszych rozważań. Jej książka inspiruje bowiem, by poruszyć zasadnicze dla artykułu zagadnienia. I tak, 1) zachodzące procesy ekologizacji humanistyki zachęcają, by zamiast ujmować przestrzeń obozową w binarnych kategoriach żywe/martwe, przyjąć perspektywę eko-nekro i potraktować ją raczej w kategoriach nekrowitalnych relacji i życiodajnych procesów dekompozycji; 2) Holocaust Archaeologies inspiruje także do podjęcia tematu „zwrotu forensycznego" (forensic turn) i jego wpływu na prowadzone w ramach humanistyki badania miejsc zbrodni oraz na możliwości i zagrożenia wynikające z kryminalistycznego podejścia do studiów nad Holokaustem, 3) wykorzystywana w archeologii sądowej tafonomia jako nauka badająca losy ludzkich szczątków ujawnia możliwości rozwoju porównawczych (i biohumanistycznych) studiów nad ludobójstwami, wskazując na podobne sposoby postępowania ze zwłokami ofiar, powtarzające się wzorce ich deponowania i maskowania zbrodni.

27 Por.: J. Kawecki, P. Konczewski, K. Szwagrzyk, M. Trzciński Archeologia sądowa w teorii i praktyce...; A. Kola Archeologia zbrodni. Oficerowie polscy na cmentarzu ofiar NKWD w Charkowie, Wydawnictwo Naukowe UMK, Toruń 2005. Potencjalność i zasadność podejścia integrującego rozważania antropologiczne i archeologiczne badania wykopaliskowe została dostrzeżona przez grono studentów i doktórantów -autọrów laftykułów opublikowanych w książce Sztutowo czy Stutthof? Oswajanie krajobrazu kulturowego, red. Ł. Banaszak, M. Wosińska, Muzeum Stutthoff w Sztutowie, Poznań-Sztutowo 2011.

Colls pokazuje, jak wszelkie sposoby zacierania śladów zbrodni (różne sposoby anihilacji ciał ofiar) oraz maskowania grobów masowych (sadzenie drzew i innych roślin), zwłaszcza przy zastosowaniu nowoczesnych metod archeologii sądowej, okazały się nieskuteczne. C. Sturdy Colls $O$ tym, co minęło, lecz nie zostało zapomniane. Badania archeologiczne na terenie byłego obozu zagłady w Treblince, przeł. E. Fełska, J. Giebułtowski, "Zagłada Żydów. Studia i Materiały” $2012 \mathrm{nr} 8$, s. 96 i n. [83-118]. 


\section{Ekologia dekompozycji}

Rozpatrywanie ontologii martwego ciała uświadomiło mi, że humanistyka ze swoim hermeneutycznym podejściem i niechęcią do „twardej nauki” ogranicza (a czasami wręcz blokuje) potencjał badawczy, który tkwi w tak różnorodnym i wielowymiarowym materiale badawczym, jakim są ludzkie szczątki i inspiracje płynące z metod ich badania w naukach przyrodniczych. Zaczęłam zatem sytuować rozważania w kontekście szeroko rozumianej humanistyki ekologicznej i forensyki, które otworzyły możliwości podjęcia badań w opcji tzw. radykalnej interdyscyplinarności łączącej humanistykę, nauki społeczne, sztukę i nauki przyrodnicze. Oferowana przez nią rama interpretacyjna kieruje zainteresowania na dwa związane ze sobą procesy, które podtrzymują życie różnych ekosystemów, tj. na proces fotosyntezy oraz rozkładu (dekompozycji). Prace ekologów pozwalają rozumieć dekompozycję w sposób pozytywny, jako proces dostarczający energii i składników odżywczych niezbędnych do podtrzymywania życia. Kierując się ich podejściem, dekompozycję będę tutaj rozumiała jako wieloetapowy fizykochemiczny i biologiczny proces rozkładu (i rozpadu) złożonych związków organicznych na związki proste, takie jak m.in. dwutlenek węgla, woda, jony wodorowe, podczas którego następuje uwolnienie energii cieplnej, prowadzący do mineralizacji jako ostatecznego efektu procesu rozkładu. Dużą rolę w dekompozycji odgrywają destruenci (bakterie, grzyby) - organizmy odżywiające się martwą materią organiczną, którzy przyczyniają się do mineralizacji materii organicznej. Rozkład może także zachodzić bez udziału organizmów żywych, pod wpływem tlenu, wody, ciepła (pożary, zalewy itd.). Ekolodzy uświadamiają, że gdyby nie istniał proces rozkładu, materia nieorganiczna pozostawałaby bezużyteczna; nie mógłby także sprawnie przebiegać proces fotosyntezy, a system przestałby istnieć. Utrzymanie równowagi ekosystemu zależy zatem od możliwości rozkładu jego obumarłych elementów. W efekcie tego procesu związki węgla (pierwiastka stanowiącego podstawę wszelkich form życia na Ziemi) wykołzystywàne są wtórniejako budulec dla nowych form życia (cykliczny obieg węgla w przyrodzie) ${ }^{30}$.

30 Po śmierci człowieka procesy gnilne uwalniają węgiel do atmosfery, gleby oraz powietrza. Żywe organizmy pochłaniają uwolniony węgiel w celu wytworzenia nowego życia. Zjawisko to jest elementem cyklu, który naukowcy nazywają obiegiem węgla w przyrodzie. Węgiel jest budulcem tego, co żywe. Wszystkie żywe stworzenia są zbudowane z pierwiastków, z których najważniejszymi i najliczniej występującymi są tlen, węgiel, wodór, azot, wapń i fosfor. Węgiel jest spośród nich pierwiastkiem, który najłatwiej łączy się z pozostałymi, tworząc złożone związki chemiczne niezbędne do życia: cukry, skrobie, tłuszcze i białka. Zob. K. Kowalski Recyc- 
Dla przyzwyczajonego do mówienia o człowieku w kategoriach społeczno-kulturowych humanisty publikacje dotyczące rozkładu ludzkiego ciała autorstwa specjalistów od medycyny sądowej wydają się redukcyjne. Dla zilustrowania różnicy dyskursów posłużę się cytatem z artykułu autorstwa Franklina E. Damanna i Davida O. Cartera, zatytułowanego Human Decomposition Ecology and Postmortem Microbiology (2013):

Dekompozycja jest procesem mobilizacji składników odżywczych żywych niegdyś organizmów w otaczający ekosystem tak, by mogły zostać odzyskane jako żywa biomasa [...], uwolnione do atmosfery czy gleby, lub zachowane jako nieorganiczne składowe skamielin [...]. W tym procesie ludzka dekompozycja nie jest wyjątkiem i znajduje się w centrum złożonej sieci kulturowych, fizykochemicznych i biologicznych oddziaływań. Stopień zachowania/destrukcji zwłok jest wypadkową działania otaczających je populacji dekompozycyjnych, jakości zasobów ulegających rozkładowi, a także kulturowych i środowiskowych modulatorów współtworzących unikalne, aczkolwiek efemeryczne środowisko dekompozycyjne [...]. $[R]$ ozkład materii organicznej, ich biologiczna modyfikacja w otoczeniu glebowym, następuje głównie za sprawą grzybów i bakterii glebowych. Ich działanie odpowiedzialne jest w 90\% za kumulację węgla i azotu w ekosystemie [...]; w istocie dla utrzymania ciąłości cyklu składników odżywczych i energii proces dekompozycji jest drugorzędny jedynie wobec fotosyntezy [...]. „[M]ikroby są zasadnicze dla rozkładu i odzyskiwania materii niezbędnej do życia (na przykład węgla i azotu) poprzez przekształcanie detrytusu [rozkładającej się martwej materii organicznej - dop. E.D.] ludzkiej społeczności (detritus of human society)" [...]. Carter i inni (2007) rozważali rozumienie zwłok jako bogatego źródła substancji pokarmowych i energii. Zwrócili uwagę na znaczący wkład, jaki rozkładające się "\$zçątki mająw formowaniu się ziemskiego krajobrazu, tworząc zróżnicowany ośrodek biologicznej aktywności, zaznaczający się przez zwiększoną ilość węgla i azotu oraz wody (Carter i in. 2007). ${ }^{31}$

ling the Dead , Science News for Students, September" 2014 No. 27, https://student.societyforscience.org/article/recycling-dead (6.6.2015). 
Im więcej podręczników z zakresu ekologii i tafonomii (zwłaszcza kryminalistycznej) się czyta, tym szybciej można dojść do wniosku, że oferują one współczesnej humanistyce użyteczną (i pożądaną) perspektywę badawczą i platformę konceptualną pozwalającą na budowanie komplementarnego (biohumanistycznego) podejścia do rozumienia kwestii fundamentalnych, m.in. fenomenu życia i śmierci. Perspektywa ta pozwala wrócić, jak sądzę, do zmarginalizowanej idei śmierci jako formy życia, rozumianej jednak nie w sensie metaforycznym (humanistycznym, filozoficznym czy/i psychoanalitycznym), lecz biologicznym. W takiej perspektywie gleba staje się „fabryką życia”, a martwi i ich szczątki okazują się niezwykle efektywnymi sprawcami (dead agents) ${ }^{32}$. Nie można ich zatem traktować jako bierne przedmioty. Groby zaś stają się rodzajem przestrzennych ekosystemów, w których zachodzą złożone procesy życiowe.

W świetle przedstawionych powyżej idei, rozważając miejsce archeologii sądowej w badaniach nad Holokaustem, nie zajmuję się zwyczajowo podejmowaną w tym kontekście sprawą odkrywania masowych grobów i innych dowodów zbrodni oraz identyfikacją ofiar, ale interesują mnie naturalne procesy rozkładu ludzkich szczątków i ich współczesna kondycja jako czynniki kształtujące poobozowe przestrzenie; interesuje mnie środowiskowa historia grobów masowych. Uważam bowiem, że wobec wzrostu świadomości

W innym miejscu Carter pisze, że „ekologia procesów glebowych zachodzących w grobach [...] może stać się kluczowym polem badań procesu obiegu węgla oraz składników odżywczych, procesu formowania się materii organicznej w glebie oraz relacji między bioróżnorodnością a funkcjonowaniem ekosystemów”. Dalej czytamy: „Zwłoki martwego ssaka są wysokojakościowym źródłem (niska zawartość węgla i azotu, wysoka zawartość wody), które podczas dekompozycji uwalnia do gleby intensywne i skoncentrowane porcje węgla oraz substancji odżywczych. [...] Trupie związki są natychmiastowo wchłaniane przez podziemne roślinne i zwierzęce zbiorowości, co skutkuje formowaniem się silnie skoncentrowanych żyznych obszarów nazywanych wyspami rozkładu zwłok [cadaver decomposition island; CDI]. CDI pozostają w ścisłym związku ze wzrostem mikrobiologicznej biomasy glebowej i mikrobiologicznej aktywności (mineralizacja węgla), a także zwiększeniem obecności nicieni w glebie. Każda z powstałych wysp jest zróżnicowanym zaburzeniem naturalnym, które oprócz uwalniania energii i substancji odżywczych w obręb szersźego ekosystemu, działa jako ośrodek pobierania materii z martwych owadów, pancerzyków i kokonów, fekaliów (a także z padlinożerców, zwierząt gospodarskich oraz drapieżników) oraz piór (ptasich padlinożerców i drapieżników). Jako taka, każda z wysp przyczynia się do wzrostu heterogeniczności krajobrazu. Co za tym idzie, CDI są unikalnymi habitatami dla różnego rodzaju much, żuków i początkowej wegetacji roślin, co wzbogaca bioróżnorodność ziemskich ekosystemów". D.O. Carter, D. Yellowlees, M. Tibbett Cadaver Decomposition in Terrestrial Ecosystems, "Naturwissenschaften" January 2007 Vol. 94, No. 1, s. 20 oraz fragment abstraktu, S. 12 [12-24].

32 J. Carey Crucial Role of Belowground Biodiversity, "PNAS” (Proceedings of the National Academy of Sciences of the United States of America) 2016 Vol. 113, No. 28, s. 7682-7685. 
ekologicznej troska o te przestrzenie w przyszłości może być podtrzymywana nie tylko (czy nawet nie tyle) z racji cywilizacyjno-kulturowych (opieka nad miejscami pamięci i poszanowanie sacrum przestrzeni-depozytariuszy szczątków jako wyraz człowieczeństwa), lecz także ekologicznych (genius loci i wartość tych miejsc jako enklaw specyficznej roślinności i często wymierających już gatunków). Jak bowiem dowodzą badania, miejsca grobów masowych (i przestrzenie starych cmentarzy) stanowią specyficzne „wyspy ekologiczne" - enklawę gatunków roślin (m.in. reliktowych), a także ssaków i ptaków, często takich, które są zagrożone wyginięciem ${ }^{33}$. Prężnie rozwijająca się geomikrobiologia zwraca ponadto uwagę, że znajdujące się na takich terenach kamienie, nagrobki i pomniki same w sobie są przestrzeniami dynamicznych procesów życiowych i stanowią mikrohabitat dla różnych alg, bakterii, grzybów i porostów, które przekształcają ich powierzchnię ${ }^{34}$.

Rośliny są nie tylko ekoświadkami, lecz także specyficznymi materiałami dowodowymi (botanika sądowa), np. korzenie drzewa mogą wskazać, jak długo ciało znajdowało się w ziemi, a ziarna na możliwe jego przemieszczenie. Występowanie na danym terenie specyficznych, nietypowych dla miejsca gatunków roślin może także pomóc zlokalizować położenie grobu masowego (stąd mówi się o roślinach jako wskaźnikach grobu - grave indicators, post-burial indicators). Zob.: D. Bajerlein, M. Wojterska, Ł. Grewling, M. Kokociński, Botanika sadowa-stan wiedzy i możliwości zastosowania w praktyce śledczej, „Problemy Kryminalistyki” 2015 No. 289 (3), s. 25 i n. [20-32]; T.L. Dupras, J.J. Schultz, S.M. Wheeler, L.J. Williams Forensic Recovery of Human Remains: Archaeological Approaches, CRC Press, Boca Raton 2006, s. 100 i n. i s. 237 i n. Badania pokazują, że w klimacie umiarkowanym miejsca zalegania szczątków najczęściej porasta bylica pospolita (Artemisia vulgaris L.), pokrzywa zwyczajna (Urtica dioica L.) i piołun (Artemisia abshintium L.). Zob.: P. Konczewski Archeologia sq̨dowa w praktyce, w: J. Kawecki, P. Konczewski, K. Szwagrzyk, M. Trzciński Archeologia sądowa w teorii i praktyce, s. 131-132 [113-187]. O rodzajach i roli roślin rosnących na miejscach grobów masowych pisze także Józef Żychowski Wpływ masowych grobów z I I ll wojny światowej na środowisko przyrodnicze, Wydawnictwo Naukowe Akademii Pedagogicznej, Kraków 2008. „Botaniczne archiwum” przedstawiające różnorodność roślin znajdujących się na terenie byłego obozu w Treblince przedstawia Elżbieta Janicka w pracy Zielnik. Katalog wystawy: Sztuka polska wobec Holocaustu (Polish Art and the Holocaust), red. M. Budkowska, M, Mutermilch, Żydowski Instytut Historyczny, Warszawa: 2013 oraz tejże Hortus Judeorum. Refleksje oddechowe ipokarmowo-trawienne na marginesie pracy "Miejsce Nieparzyste", w: Imhibition, red. E.M. Tatar, R. Dziadkiewicz, Muzeum Narodowe w Krakowie-Korporacja Ha!art, Kraków 2006. Pisze na ten temat Jacek Małczyński Krajobrazy Zagłady. Przyroda w przedstawieniach i miejscach pamięci Holocaustu, 2015 (praca doktorska, Wydział Nauk Historycznych i Pedagogicznych, Uniwersytet Wrocławski). Zob. także: A. Rydzewska Zabytkowe cmentarze ewangelickie północnej Wielkopolski, Wydawnictwo Uniwersytetu Przyrodniczego w Poznaniu, Poznań 2013; R. Dębicz Zieleń cmentarzy w krajobrazie wsi Dolnego Śląska, Uniwersytet Przyrodniczy we Wrocławiu, Wrocław 2012, s. 151. 
Na przykład porosty (grzyby zlichenizowane; organizmy żyjące w symbiozie z bakteriami i zielenicami; komponent grzybowy zwany jest mykobiontem), które istnieją 400 milionów lat, są uznawane za „rośliny pionierskie”35. Mogą przetrwać w nieprzyjaznym środowisku (np. przy braku wody przechodzą w stan uśpienia), ale są wrażliwe na zanieczyszczenia środowiska. Stąd stosuje się je jako bioindykatory, które pozwalają określić jakość powietrza. Porosty tworzą tzw. plechy, a obserwacja przyrostu plech jest alternatywną wobec dendrochronologii oraz metody węgla ${ }^{14} \mathrm{C}$ metodą datacji określanej jako lichenometria. Pozwala ona badać nie tylko zmiany klimatyczne i tempo sukcesji ekologicznej, lecz także czas powstania starych budowli. Jeżeli zaakcentujemy ten sposób myślenia, to perspektywa ekologiczna powinna stać się koniecznym i niezbędnym elementem zarządzania miejscami poobozowymi (zwłaszcza sposobem ich konserwacji).

\section{Dehumanizacja przez dekompozycję}

W przypadku Holokaustu, a także innych ludobójstw i masowych mordów dehumanizacja i depersonalizacja są uważane za warunki konieczne do ich zaistnienia. Łatwiej bowiem zabić człowieka, jeżeli wcześniej pozbawi się go godności, imienia oraz dobytku, nazwie szczurem, wszą czy karaluchem i zmieni w formę „nagiego życia” (Agembenowskie nuda vita) kierującą się instynktem przetrwania. Kiedy jednak martwe ciało ofiary zostaje włączone w przestrzeń podziemnego ekosystemu i poddane jest procesom rozkładu

S. Scheerer, O. Ortega-Morales, Ch. Gaylarde Microbial Deterioration of Stone Monuments - An Updated Overview, „Advances in Applied Microbiology” 2009 Vol. 66, s. 97-139.

Warto w tym miejscu przywołać biologa Scotta Gilberta, który znany jest z powiedzenia, że "Wszyscy jesteśmy porostami” (We are all lichens). Opierając się na wynikach badań biologii molekularnej i odwołując do teorii symbiozy, Gilbert wskazuje, że podważają one nasze ro-

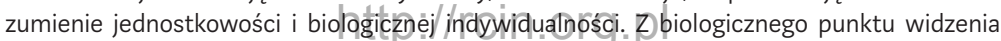
jesteśmy holobiontami, na który składa się organizm-gospodarz wraz ze wszystkimi koloniami symbiontów, tj. mikroorganizmami (bakterie, wirusy, grzyby składające się na mikrobiom) zasiedlające szczególnie przewód pokarmowy. Holobiont jest zatem nowym modusem indywidualności. Co więcej, to właśnie holobiont, a nie gatunek, staje się jednostką ewolucji. S.F. Gilbert We are all lichens: How symbiosis theory is re-configuring critical biological boundaries (abstrakt wykładu na Penn State University, 16 listopada 2015, http://iah.psu.edu/events/ boundaries-scott-gilbert-1 (30.11.2016)). Por. także: R. Guerrero, L. Margulis, M. Berlanga Symbiogenesis: The Holobiont as a Unit of Evolution, "International Microbiology" 2013 Vol. 16, s. 141 [133-143]; S.F. Gilbert, J. Sapp, A.I. Tauber A Symbiotic View of Life: We Have Never Been Individuals, "The Quarterly Review of Biology" December 2012 Vol. 87, No. 4, s. 325-341. 
(redukcja ciała do materii pochodzenia organicznego), następuje inny proces jego dehumanizacji: dekompozycja, humifikacja i mineralizacja.W takim przypadku odczłowieczenie staje się naturalnym sposobem istnienia w nowym środowisku glebowym uważanym za jedno z najbardziej różnorodnych na Ziemi ${ }^{36}$. Dehumanizacja następuje tutaj nie przez związaną z negatywną przemocą, mającą na celu wykluczenie, upokarzającą animalizację (przyrównanie do zwierzęcia lub insekta) czy mechanizację (porównanie do automatu, maszyny czy robota), ale na zasadzie przemiany organicznej, którą określam mianem metamorfozy nekrotycznej - przekształcenia ciała w humus (humifikacja), gdzie dekompozycja znamionuje proces inkluzji.

Podążając tropem naukowców zajmujących się badaniem gleby rozumianej jako złożony i żyjący organizm, będę tutaj używała słowa humus z jednej strony na określenie próchnicy powstałej w wyniku rozkładu materii organicznej, z drugiej zaś specyficznej formy istnienia i figuracji zbiorowej persony - rodzaju materii, która uległa procesowi dekompozycji i „została wykorzystana i przekształcona przez różnorodne mikroorganizmy zamieszkujące glebę"37. W tym sensie ludzkie szczątki jako element humusu stają się „naturalnym produktem biologicznej aktywności środowiska glebowego, powstającym w wyniku transformacji resztek organicznych pod wpływem odziaływania makro- i mikroorganizmów"38.

Proces dehumanizacji, tj. od-stawania się człowiekiem (un-becoming human) w sensie kulturowym, jako humifikacji (przybieranie postaci postludzkiego bytu - humusu), stanowi podstawę rozważań dotyczących ontologii martwego ciała i szczątków. Otwiera możliwości rozumienia ludzkich szczątków jako elementów symbiotycznych zbiorowości, złożonych z bytów organicznych i nieorganiczych, które egzystują w różnych sferach, na różny sposób i stale mieszają się ze sobą (commingling $\left.{ }^{39}\right)$. Owo "mieszanie się" i przemieszczanie świadczy o ich sprawczości, która rozumiana w sensie stałego ruchu, zmiany postaci, wchodzenia w relacje, a co za tym idzie zdolności

\section{http://rcin.org.pl}

36 C. Carey Crucial Role of Belowground Biodiversity, s. 7683.

A.Bot, J. Benites The Importance of Soil Organic Matter. Key to Drought-Resistant Soil and Sustained Food Production , "FAO Soil Bulletin” Rome 2005 No. 80 (Food and Agriculture Organization of the United Nations), s. 8.

Strona Jerzego Webera (Instytut Nauk o Glebie i Ochrony Środowiska, Uniwersytet Przyrodniczy we Wrocławiu), http://karnet.up.wroc.pl/ weber/def1.htm (12.11.2016). 
do wywoływania zmian w otoczeniu (np. wpływa na skład chemiczny wód gruntowych, gleby, powstawanie osuwisk itd.).

Można zatem powiedzieć, że procesy dehumanizacji prefigurują procesy humifikacji. Związki humusowe zastępują związki międzyludzkie. Rozkład i synteza zaś, jako kolejne etapy procesu humifikacji, stanowią podstawy dynamicznego bytowania szczątków rozpatrywanych w ramach złożonych procesów biochemicznych. A zatem, podczas gdy w symbolicznym świecie kultury dehumanizacja oznacza zerwanie więzi i poczucia solidarności gatunkowej oraz wyłączenie z dominującej (opresyjnej) zbiorowości ludzkiej, to w świecie natury oznacza włączenie w znacznie szerszą zbiorowość bytów, z których tylko niektóre są postludzkie w tym sensie, że kiedyś były ludźmi. Dehumanizacja martwego ciała (nabycie przez niego statusu bytu postludzkiego) - powtórzę - jest zatem warunkiem sine qua non włączenia go w zbiorowość różnych form organicznego (w wielogatunkową wspólnotę) i nieorganicznego istnienia. Można wyprowadzić z powyższych rozważań wniosek, że człowieczeństwo jest stanem przejściowym i kwestią stopnia. Ludźmi jesteśmy „tu i teraz”. Zaś badanie nekrosolu (gleb cmentarnych) znajdującego się na terenach poobozowych (dziedzictwo gleb) stanowi w świetle powyższych rozważań istotny element badań dziedzictwa ludzkości.

\section{Tafonomia czyli pośmiertna historia organizmów}

W proponowanym tutaj ujęciu kryminalistyka, a zwłaszcza zajmująca się procesami dekompozycji tafonomia, staje się kluczowa dla badań prowadzonych w obrębie zorientowanych na radykalną interdyscyplinarność nauk humanistycznych i społecznych. Tafonomia (taphos - grób; nomos - prawo) została zdefiniowana w latach 40. XX wieku przez radzieckiego paleontologa Iwana Jefremova jako nauka o prawach tworzenia się osadów czy osadzania się (the science of the laws of embedding), która zajmuje się badaniem przenikania szczątków organicznych z biosfery do litosfery, a także procesem ich fosylizacji ${ }^{40}$. Jest ona nauką przyrodniczą (uznawaną za gałąź paleontologii czy ekologii), a jako transdyscyplinarna dziedzina wiedzy wiąże się z takimi dyscyplinami pokrewnymi jak paleoekologia, stratygrafia i geologia. Odkąd

40 Iwan Jefremov Taphonomy New branch of Paleontology "Pan-American Geologist" 1940 Vol. 74, No. 2. Por. także: R.E. Martin Taphonomy. A Process Approach, Oxford University Press, Cambridge-New York-Melbourne: 1999, s. 1. 
jednak zajmuje się także „zapisaną w skałach historią Ziemi i żywych organizmów"41, można ją uznać - jak chcieliby tafonomiści - za naukę historyczną w ścisłym tego słowa znaczeniu.

Historycy mają dość wąskie rozumienie tego, czym jest historia, ogranicza się ono do jej definiowania przez pryzmat wydarzeń związanych przede wszystkim z szeroko rozumianą sferą kultury i ich zapisów źródłowych. Jednak w obliczu rosnących zainteresowań Wielką Historią (Big History), historią planetarną (planetary history), historią głęboką (deep history) czy historią wielogatunkową (multispecies history), tafonomia jako nauka historyczna zdaje się wartym uwagi podejściem w badaniu śladów przeszłości, m.in. ludzkich szczątków zachowanych w różnej postaci. Co więcej, ponieważ w ramach tafonomii tworzy się modele, formułuje prawa i poszukuje wzorców (takich jak chociażby charakterystyczne wzory dekompozycji ciała człowieka czy też „typy specyficznych praktyk grzebalnych związanych z ludobójstwem" ${ }^{\prime 2}$ ), może ona pomóc w reintrodukcji nauk ścisłych do „miękkiej” humanistyki interpretatywnej i stanowić ważny komponent współczesnych badań przeszłości, zwłaszcza porównawczych studiów nad ludobójstwami (a także ludobójstwami i ekobójstwami). Proces pozyskiwania informacji ze źródeł w obu przypadkach jest podobny i polega na śledzeniu historii wstecz - od źródła, jakim są szczątki (efekt przeszłego wydarzenia), do przyczyn tego wydarzenia, czyli momentu śmierci. Być może zatem warto, by te praktykowane $\mathrm{w}$ ramach humanistyki badania martwego ciała, które odwołują się do (czy opierają na) tafonomii, wyodrębnić i nazwać historią tafonomiczną.

Miejsca masowych zbrodni i cmentarze stanowią wypadkową różnych przenikających się procesów zarówno społeczno-politycznych i kulturowych, jak i biologicznych, klimatycznych i geologicznych. W takim ujęciu ponownie uwidacznia się zasadność perspektywy długiego trwania, która pozwala obserwować procesy przekształceń i przemieszczania się organicznych i nieorganicznych obiektótw (artefalktówi ekofaktów) z biosfery do litosfery oraz procesy ich naturalnej prezerwacji. Warto w tym miejscu nawiązać do wprowadzonego przez Iana D. Hansona pojęcia „krajobrazu forensycznego",

41

42

Tamże, s. 5 .

D. Komar Patterns of Mortuary Practice Associated with Genocide. Implications for Archaeological Research, "Current Anthropology” 2008 Vol. 49, No. 1, s. 123-133. Podobnie Colls pisze o "wzorcach depozycyjnych" (patterns of disposal). C. Sturdy Colls Holocaust Archaeologies..., S. 283 . 
w badaniu którego groby masowe stanowią - jak to określa, „nagłe zdarzenie depozycyjne”, a ciało „stratygraficzny depozyt"43. W takim ujęciu pomocna staje się dziedzina którą określa się mianem tafonomii krajobrazowej (landscape taphonomy). Dużą wagę przywiązuje się w niej do obserwacji i badania procesów tworzenia się krajobrazu także w kontekście zjawisk zachodzących pod ziemią. Złożenie ciała, jego rozkład, dokonywane w różnych celach naruszanie grobu (rabowanie, ekshumacje) stanowią ważny czynnik zaburzający stratyfikację warstw ziemi. Istotne przy tym jest to, że podejście takie pozwala na neutralizację wpływu antropocentrycznej sprawczości (tj. zwyczajowemu przypisywaniu zbyt dużej wagi ludzkim działaniom) na tworzenie krajobrazu, a także uzależnienia istnienia jego samego od ludzkiej percepcji (krajobraz istnieje o tyle, o ile jest postrzegany i doświadczany przez ludzi). Takie podejście jest ograniczające, a badacze zwracają uwagę na potrzebę ujęć bardziej holistycznych i wielodziedzinowych, które uwydatniają rolę procesów biologicznych, fizycznych, glebowych, geologicznych, a także wypływ żyjących na danym terenie zwierząt, owadów, roślin na to, co w konsekwencji jawi sięjako krajobraz ${ }^{44}$, a w przypadku prowadzonych tutaj rozważań - przestrzeń grobów masowych czy/i cmentarzy.

Także tafonomia jako specyficzna dyscyplina nauk kryminalistycznych, która jest szczególnie ważna w procesie identyfikacji grobów masowych, może okazać się niezwykle pomocna w badaniach prowadzonych w ramach środowiskowej i wielogatunkowej historii Holokaustu. Archeolodzy często określają groby masowe mianem „anomalii geofizycznej”, zakładając wykopy, badając profil litologiczno-stratygraficzny i mierząc wskaźniki zmian terenu i struktur ziemi wobec otoczenia. William D. Haglund, Melissa Connor, Douglas D. Scott w artykule The Archaeology of Contemporary Mass Graves (2001) podają przydatną w moich dalszych rozważaniach definicję grobu jako „miejsca pochówku kiedyś żyjących istot” (the burial of once-living beings). Grób masowy z kolei charakteryzowany jest ich zdaniem przez ilość ciał, które się w nim znajdują. Niejest tójednakjedynyjego wyznacznik. Niektóre

43 I.D. Hanson The Importance of Stratigraphy in Forensic Investigation, w: Forensic Geoscience: Principles, Techniques and Applications, ed. K. Pye, D.J. Croft, Geological Society, London 2004, s. 40-42 [39-47]. Koncepcję Hansona w kontekście rozważań humanistycznych rozwinęła R.E. Cyr The "Forensic Landscapes” ofSrebrenica, "Култура/Culture” 2014 nr 5, s. 81-91.

44 O.Burger, L.C. Todd, P. Burnett The Behavior of Surface Artifacts: Building a Landscape Taphonomy on the High Plains, w: Archaeological Landscapes on the High Plains, ed. L.L. Scheiber, B.J. Clark, University Press of Colorado, Boulder 2008, s. 207 [203-236]. 
definicje grobu masowego podkreślają bowiem sposób depozycji ciał i brak szacunku wobec nich, co przejawia się np. w niedbałym wrzucaniu ciał do dołu ${ }^{45}$. Ważne jest także, czy ciała przylegają do siebie, czy są odseparowane. Inny jest bowiem grób, gdzie w wykopie osobno ułożonych jest wiele niestykających się ciał, a inny, gdzie zwłoki nakładają się na siebie. Ich ułożenie w zasadniczy sposób wpływa na procesy rozkładu. W przypadku przyległości „tworzy się bowiem specyficzne mikrośrodowisko, które wpływa na stan ich zachowania. Podczas gdy ciała na krawędziach grobu ulegają zeszkieletowaniu, te znajdujące się w środku przez lata od depozycji mogą zachować tkanki miękkie"46.

Nowe obszary badawcze, takie jak entomologia kryminalistyczna, ekologia procesów glebowych zachodzących w grobach, studia nad mikrobiomami grobów (nekrobiomami ${ }^{47}$ ), a także mykologia kryminalistyczna ${ }^{48}$, moga dostarczyć inspiracji do budowania nowego aparatu pojęciowego, a także rozszerzyć ramy interpretacyjne analiz zjawisk badanych w ramach studiów nad Holokaustem i innymi ludobójstwami ${ }^{49}$.

\section{Realizm kryminalistyczny}

Fascynując się kryminalistyką, nie można jednak zapominać, że specyficzny żargon, którym się posługuje: zabójstwo, miejsce zbrodni, dowód (poszlaka, ślad, dowód rzeczowy), traseologia, autopsja, corpus delicti, materiał

45 E.Jessee, M. Skinner A Typology of Mass Grave and Mass Grave-Related Sites, „Forensic Science International" 2005 Vol. 152, , s. 56 [55-59].

W.D. Haglund, M. Connor, D.D. Scott The Archaeology of Contemporary Mass Graves, „Historical Archaeology" 2001 Vol. 35, No. 1, s. 57-58 [57-69].

W 2014 roku kryminolog Gulnaz Javan z Alabama State University w Montgomery wraz ze swymi współpracownikami opublikował pierwsze studium dotyczące mikrobiomu grobu (thanatomicrobiome). Kompleksowe wyniki bädań zostały przedstawione w artykule: S.J. Finley, M.E. Benbow, G. Javan Microbial Communities Associated with Human Decomposition and their Potential Use as Postmortem Clocks., ,I International Journal of Legal Medicine" May 2015 Vol. 129, No. 3, s. [623-632].

Więcej na temat grzybów jako użytecznych narzędzi w badaniach kryminalistycznych w: D.L. Hawksworth, P.E.J. Wiltshire Forensic Mycology: The Use of Fungi in Criminal Investigations, „Forensic Science International” 2011 Vol. 206, , s. 2 [1-11]; M. Hitosugia, K. Ishiib, T. Yaguchic et al. Fungi Can be a Useful Forensic Tool, "Legal Medicine” July 2006 Vol. 8, No. 4, s. 240-242. 
genetyczny, analiza DNA, kontaminacja, patologia, balistyka, toksykologia, serologia, biegli sądowi, świadkowie, prawo kryminalne itd., nie oferuje neutralnych, opisowych terminów, ale normatywne, preskryptywne. Jako takie dotyczą one nie epistemologii, a ontologii, i są kategoriami postępowania raczej niż poznania. Kiedy zatem obserwujemy „zwrot forensyczny” pociągający zarówno humanistów, jak i badaczy nauk społecznych i zauważamy coraz częstszą obecność specyficznej terminologii charakteryzującej dyskurs tej dyscypliny w narracjach o przeszłości, zdajemy sobie sprawę, że to nie realistyczny dyskurs XIX-wiecznej powieści wyznacza wizję świata i ramy możliwych zmian społecznych, ale specyficzna fantazja nauki i technologii (której częścią jest imaginarium kryminalistyczne), oferowana zarówno przez dyskurs akademicki, jak i kulturę popularną w stylu „fantastyczno-naukowego realizmu kryminalistycznego" (sci-fiforensic realism) ${ }^{50}$. Literatura fantastyczno-naukowa nie dostarcza dzisiaj fikcyjnej, nierealistycznej wizji przyszłości, ale staje się coraz częściej komplementarną do nauk ścisłych i badań technologii (STS) dziedziną wiedzy. Jak zauważył Tom Idema, coraz częściej „fikcja naukowa, a co za tym idzie również literatura i sztuka, może być odczytywana nie tylko jako krytyczny komentarz dotyczący biotechnonauki, ale jako sposób myślenia o przyszłości (ludzkiego) życia poprzez tę naukę"51.

Zanim zatem z entuzjazmem zaczniemy podchodzić do zwrotu kryminalistycznego, spróbujmy przewidzieć, jakie konsekwencje może on wywołać. Rola archeologii i antropologii sądowej w badaniach Holokaustu jest, rzecz jasna, nieoceniona (chociażby w identyfikacji ofiar, wskazywaniu sposobu i czasu śmierci, metod postępowania ze zwłokami, a także lokalizacji i weryfikacji miejsc występowania grobów masowych oraz ich ilościowej zawartości). Bez wątpienia jako konceptualna platforma forensics pozwala przemyśleć - na przykład - co to znaczy być człowiekiem, czym jest życie, czym jest zbiorowość. Pozwala także budować pomost między naukami ścisłymi/przyrodniczymi i humanistyką. Zwróćmy jednák)uwąge, że zwrot kryminalistyczny dla wielu badaczy polega na „odwróceniu się od ludzkich świadków (human witnesses) w kierunku obiektów materialnych, które potrafią mówić czy nawet

S. Keturah Deutsch, G. Cavender CSI and Forensic Realism, "Journal of Criminal Justice and Popular Culture" 2008 Vol. 15, No. 1, s.34-53.

51 T. Idema Toward a Minor Science Fiction: Literature, Science, and the Shock of the Biophysical, "Configurations" Winter 2015 Vol. 23, No. 1, s. 38 [35-59]. 
zeznawać" ${ }^{2}$. Co więcej, zwrot ten identyfikuje się z hasłami „normalizacji ekshumacji jako metody badania ludzkich szczątków na skalę masową"53. Idea „kości, które nie kłamią", nadrzędności szczątków jako podstawowego dowodu historycznego, wobec innych typów źródeł i jako najbardziej wiarygodnego świadka oraz znajdującej się w ciele zmarłego prawdy forensycznej (forensic truth), która weryfikuje wszystkie inne prawdy, staje się podstawowym sposobem społecznych zmagań z pamięcią traumatycznej przeszłości. Przy takich deklaracjach warto na zwrot forensyczny spojrzeć z szerszej perspektywy i potraktować go jako „wdzieranie się" dyskursu forensycznego do humanistyki i wziąć pod uwagę możliwość jego wykorzystania przez dominującą w danym czasie władzę w celach prowadzenia polityki (historycznej) i sterowania pożądanymi zmianami społecznymi.

52 Jest to cytat z abstraktu opisującego serię wykładów zatytułowanych: „Regarding Objects: A Survey of the Forensic Turn", które odbyły się w Institute for Contemporary Art w Berlinie w 2015 roku, http://matteopasquinelli.com/forensic-turn/ (14.05.2015). Należy dodać, że chodzi ogólnie o wzrastające znaczenie nie-ludzkich świadków, nie tylko rzeczy, lecz także owadów, roślin czy grzybów (mykologia sądowa). (Por. także: przypis 32 tego artykułu). W jednym z odcinków serialu CSI - Sex, Lies and Larvae (2000), rozmawiając o nagromadzonych w trakcie śledztwa dowodach, Sara Sidle mówi do oficera śledczego Gila Grissoma, że ten zawsze jej przypomina, iż „znacznie lepiej posiadać choćby fragment dowodu rzeczowego (forensic evidence), niż dziesięciu naocznych świadków". W odcinku tym, Grissom do ustalenia czasu śmierci i postępowania ze zwłokami kobiety stosuje entomologię sądową (wykorzystanie w ekspertyzach śledczych owadów i ich larw znalezionych na czy przy zwłokach, m.in. nekrofagów, takich jak muchówki i chrząszcze). Owady, jak mówi, są „pierwszymi świadkami zbrodni". Zob. także: R. Skowronek, Wykorzystywanie entomologii w kryminalistyce i medycynie sq̨dowej, w: Problemy środowiska i jego ochrony, t. 20, red. P. Miguła, M. Nakonieczny, Centrum Studiów nad Człowiekiem i Środowiskiem Uniwersytetu Śląskiego, Katowice 2012, s. 115-137.

Mając na uwadze ofiary Holokaustu, których ciała w obozach śmierci były palone, warto zwrócić uwagę, że w świetle dzisiejszych badań prowadzonych w ramach biologii molekularnej badacze są w stanie uzyskać więcej informacji na temat pochodzenia organicznych związków. (Wywiad z zooarcheologiem| † Krishem Säétahem, Stafford Archaeology Center, 21.05.2015.) Niektórzy naukowcy twierdzą, że można wyekstrahować DNA ze skremowanych szczątków (co zależy m.in. od temperatury kremacji), ale wielu innych uznaje to za wątpliwe, wskazując raczej na badania ich składu chemicznego (m.in. metodą fluorescencji rentgenowskiej, XRF i spektroskopii emisji optycznej, ICP-OES) jako bardziej wiarygodne. Zob.: T.L. Van Deest, M.W. Warren, K.L. Bolhofner, Advances in the Anthropological Analysis Cremated Remains, w: A Companion to Forensic Anthropology, ed. D. Dirkmaat, Blackwell, Oxford 2012, s. 426 i n. [418431]. Por. także: S. Naji et al., Recovery Methods for Cremated Commingled Remains: Analysis and Interpretation of Small Fragments Using a Bioarchaeological Approach, w: Commingled Human Remains: Methods in Recovery, Analysis, and Identification, ed. B. Adams, J. Byrd, "Academic Press" 2014 S. 33-56. 


\section{Zakończenie: NekroPrzyszłości}

Społeczeństwo składa się z trzech konstytutywnych elementów: zmarłych, żyjących obecnie oraz nienarodzonych. Spoglądając w przyszłość ludzkich zbiorowości i biorąc pod uwagę gwałtowny rozwój technologii, można wyobrazić sobie, że martwe ciało i różne jego formy mogą stać się w przyszłości (na znacznie większą skalę niż obecnie) zarówno użytecznym materiałem organicznym i genetycznym dla nienarodzonych, jak i rezerwuarem organów, tkanek i kości dla żyjących, a także zasobem wykorzystanym w celach klonowania oraz nawozem dla gleby. W ten sposób granice między tym, co żywe, a tym, co martwe, będą coraz bardziej się zacierać. Ludzkość popada w coraz większą zależność od martwych (ciał), w sposób, który historycy rzadko sobie wyobrażają, kiedy dyskutują (często w sensie metaforycznym) o związkach przeszłych i obecnych pokoleń.

Zgadzam się z Jasonem N. Summerfieldem, który stwierdził niedawno, że „systemowe traktowanie zmarłych - a w taki właśnie sposób obchodzi się z nieżyjącymi państwo, zwiastuje epokę, w której tryb postępowania z umarłymi będzie mieć długotrwałe konsekwencje dla ludzkości i ludzkiej pamięci"54. Jeżeli zatem nadal chcemy uznawać grzebanie zmarłych za obowiązek i wyznacznik człowieczeństwa ${ }^{55}$, warto zadać sobie pytanie, jakie są możliwości ochrony ludzkich szczątków znajdujących się zarówno na cmentarzach, jak i w miejscach masowych mordów, przed nekrocydem (potencjalną utylizacją), a także przed „rehabilitacją” (ponownym użyciem) przestrzeni grzebalnych. Zapytałam kiedyś Donalda van Straatena - dyrektora Domu Pogrzebowego Alta Mesa w Palo Alto (Kalifornia), jaki jest najlepszy sposób uchronienia szczątków przed możliwą profanacją. "Skremować i rozsypać” - odpowiedział bez wahania. Nie jestem pewna, czy jest to sposób do końca efektywny. Niemniej jednak większe szanse na „spokojny odpoczynek”

54 J.N. Summerfield Comments on the Potter's Field: The Future of Mass Graves, "Quinnipiac Probate Law Journal" 2014 Vol. 28, No. 1, s. S. 29 [23-47].

55 Należy jednak przyznać, że jak dowodzą badania specjalistów od zachowań zwierząt, troska o martwe ciało nie jest cechą typowo ludzką. Także i inne zwierzęta (zwłaszcza człekokształtne, lecz także słonie) przejawiają takie zachowania jak gromadzenie się wokół ciała, oglądanie i dotykanie oraz czyszczenie. W przypadku szympansów zaobserwowano noszenie przez matki ciałzmarłych niemowląt nawet przez kilka miesięcy. Jak twierdzą prymatolodzy, „szympansy przejawiają wiele zachowań przypominających ludzkie reakcje na śmierć bliskich, które pozbawione są jednak symboli i rytuałów związanych ze śmiercią". J.R. Anderson, A. Gillies, L.C. Lock

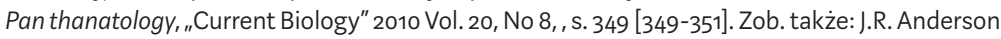
Comparative Thanatology, "Current Biology” July 112016 Vol. 26, No. 13, s. 543-576; B.J. King How Animals Grieve, University of Chicago Press, Chicago-London 2013. 
mają szczątki rozproszone, przemieszane, zmineralizowane, a w ten sposób „ukryte" pod ziemią, niż chroniące przed rozkładem pochówki inhumacyjne, których obecność manifestują naziemne pomniki (hic iacet) ${ }^{\mathbf{5 6}}$.

Ekologiczne podejście do przestrzeni Zagłady w perspektywie długiego trwania może przyczynić się do zmiany ich postrzegania, a także sposobów zarządzania ich konserwacją. Ważne jest, jak sądzę, by przekonać się do tego, że rozważanie szczątków ludzkich w kategoriach ich naturalnego mieszania się (organic commingling) z innymi elementami ekosystemu (ich dehumanizacja związana ze zmianą w humus) nie oznacza degradacji czy/i redukcji człowieczeństwa osoby zmarłego, ale potwierdza jego potencjalne (biologiczne) istnienie. W takiej perspektywie przestrzenie grzebalne, które często rozpatruje się w kategoriach separacji, gettoizacji i wykluczania zmarłych ${ }^{57}$, stają się miejscami inkluzji, łączenia z innymi formami życia i symbiotycznego trwania. W perspektywie bardzo długiego trwania przestrzenie Zagłady widzialne w perspektywie eko-nekro stają się także figurą możliwej wspólnotowości i symbiotyczną diasporą; ekumeną różnych form życia.

Wiele wskazuje na to, że wkraczamy w epokę, gdzie to, co zazwyczaj uważane jest za nieżywe lub martwe, będzie miało szczególne i coraz większe znaczenie dla podtrzymania ziemskiego istnienia. Nie mam tu jednak na myśli „kultury śmierci”, ale inne rozumienie życia i jego miejsca w postrzeganiu procesów podtrzymujących trwanie. Żyć to znaczy móc wchodzić w relacje i zachowywać potencjał do transformacji; przekształcania siebie i otaczającego środowiska. A jeżeli tak, to śmierć jest tylko formą życia.

56 Nie sugeruję tutaj wyższości,kremacji nad pochówkiem tradycyjnym. Wskazuję jedynie, że preferowane w wielu kulturach praktyki jak najdłuższego zachowywania ciała (balsamowanie, używanie twardego drewna na trumny, budowanie sarkofagów itd.) w świetle prowadzonych wyżej rozważań bardziej narażają zmarłego na potencjalną profanację grobu i wykorzystanie ciała do różnych celów niż chowanie na sposób "przyjazny dla środowiska” przy użyciu materiałów łatwo biodegradowalnych. Zob.: J. Baudrillard Wymiana symboliczna i śmierć, przeł. S. Królak, Sic!, Warszawa 2007, s. 158 i n.

Dziękuje Jackowi Leociakowi i Annie Ziębińskiej-Witek za ważne sugestie, które przyczyniły się do wypracowania ostatecznej wersji tego artykułu, a Kornelii Kajdzie, Jackowi Małczyńskiemu i Ryszardowi Nyczowi za wsparcie i komentarze. 


\section{Abstract}

\section{Ewa Domańska}

ADAM MICKIEWICZ UNIVERSITY IN POZNAŃ

Post-Holocaust Spaces in an Ecological-Necrological Perspective

This article seeks to reconceptualize the current condition of post-Holocaust spaces from an ecological-necrological perspective. This approach is informed by ethical concerns related to the proper treatment of the dead body and human remains as well as the maintenance of burial sites. The author is using insights offered by taphonomy and the ecology of decomposition. An eco-necro perspective also allows to return to the marginalized (and forgotten) idea of death as a form of life understood in a biological sense. The graves and burial sites are considered as specific ecosystems full of complex life processes. Thus, the article claims, an ecological approach should become a necessary element in the management of the spaces of the death camps and especially of their conservation and might help to preserve the sacredness of these sites.

\section{Keywords}

human remains, necrocide, forensic archaeology, decomposition ecology, taphonomy

\section{http://rcin.org.pl}

